\title{
Biological and Structure-Activity Evaluation of Chalcone Derivatives against Bacteria and Fungi
}

\author{
Wender A. Silva, ${ }^{*, a}$ Carlos Kleber Z. Andrade, ${ }^{*, a}$ Hamilton B. Napolitano, ${ }^{a, b}$ Ivo \\ Vencato, $^{b, c}$ Carlito Lariucci, ${ }^{c}$ Miriam. R. C. de Castro ${ }^{b}$ and Ademir J. Camargo ${ }^{b}$ \\ ${ }^{a}$ LaQMOS, Instituto de Química, Universidade de Brasília, CP 4478, 70910-970 Brasília-DF, Brazil \\ ${ }^{b}$ Ciências Exatas e Tecnológicas, Universidade Estadual de Goiás, \\ BR 153, km 98, 75133-050 Anápolis-GO, Brazil
}

'Instituto de Física, Universidade Federal de Goiás, CP 131, 74001-970 Goiânia-GO, Brazil

\begin{abstract}
O presente trabalho descreve as atividades antibacterianas e antifúngicas de diversas chalconas obtidas diretamente através da condensação aldólica tipo Claisen-Schmidt das quais se determinou a concentração inibitória mínima frente a diferentes microrganismos (bactérias Gram-positivas e Gram-negativas e fungos). Estruturas no estado sólido cristalino de sete chalconas foram determinadas por análise de difração de raios X (XRD). Estudos quimiométricos foram realizados com intuito de identificar uma potencial relação entre estrutura e atividade.
\end{abstract}

The present work describes the antibacterial and antifungal activities of several chalcones obtained by a straight Claisen-Schmidt aldol condensation determined by the minimal inhibitory concentration against different microorganisms (Gram-positive and Gram-negative bacteria and fungi). Solid state crystal structures of seven chalcones were determined by X-ray diffraction (XRD) analysis. Chemometric studies were carried out in order to identify a potential structureactivity relationship.

Keywords: chalcones, biological activities, X-ray structures, theoretical calculations

\section{Introduction}

Chalcone (1,3-diaryl-2-propen-1-ones) derivatives are found widespread in natural products from pteridophytes to highly organized multicellular organisms. This class of compounds is considered as key precursors for flavonoid and isoflavonoid syntheses ${ }^{1}$ and can be directly obtained by aldol reactions under basic catalytic conditions. Chemically, they consist of open-chain flavonoids in which the two aromatic rings are joined by a three-carbon $\alpha, \beta$-unsaturated carbonyl system (Figure 1). Studies on their multiple biological activities including anti-inflammatory, ${ }^{2}$ anti-leishmania, ${ }^{3}$ antimitotic $^{4}$ and antiviral are some few examples of their broad range of action. ${ }^{5}$ In particular, chalcone systems usually show different levels of inhibition during proliferative processes of a plethora of cancer cell lines. ${ }^{6}$

The presence of hydroxyl, allyl and prenyl groups in their structures commonly potentiates their activities. ${ }^{7}$

*e-mail: wender@unb.br; ckleber@unb.br
Michael acceptor<smiles>C=C=CC=CC(=O)c1ccccc1</smiles>

Different groups increase or decrease the activity

Figure 1. General structure of a chalcone.

For instance, the inclusion of two hydroxyl groups (dihydroxychalcones) enhanced both the antitumor and lipidic antiperoxidation activities. ${ }^{8}$ Other activities have already been reported ${ }^{9-11}$ and Figure 2 shows some examples of biologically active chalcones.

Toxicity against several tumoral human cells ${ }^{12}$ renders this class an attractive alternative to commonly used taxoid compounds, which are very complex structures of low 
<smiles>COc1cc(/C=C/C(=O)c2ccc(O)cc2O)cc(OC)c1OC</smiles>

Antiviral $^{9}(\mathrm{I})$<smiles>COc1cc(OC)c(/C=C/C(=O)c2ccccc2C(F)(F)F)c(OC)c1</smiles>

Anti-inflamatory ${ }^{11}(\mathrm{III})$

Figure 2. Some biologically active chalcone derivatives.

availability. Hence, the preparation and identification of simpler low-cost compounds such as chalcone derivatives for cytotoxic tests are still inexhaustible tasks aiming at the development of new and promising biologically active readily available molecules. As part of our ongoing studies on the synthesis, characterization and in silico studies of chalcone derivatives, ${ }^{13}$ it is described herein the preparation of 21 different chalcone derivatives, three of them $(\mathbf{3 c}, \mathbf{3 f}, \mathbf{3} \mathbf{u})$ are novel compounds, and their evaluation as antibacterial and antifungal agents upon determination of the minimal inhibitory concentration (MIC) against different microorganisms (Gram-positive and Gram-negative bacteria and fungi). Moreover, solid state crystal structures of seven chalcones were determined by $\mathrm{X}$-ray diffraction (XRD) analysis. Theoretical calculation studies (structure modeling) were equally carried out in order to identify a potential structure-activity relationship.

\section{Results and Discussion}

\section{Synthesis of chalcones}

The chalcones were easily obtained from the aldol condensation of aromatic aldehydes and aromatic ketones ${ }^{14}$ (Table 1), in yields ranging from 70 to $100 \%$. Chalcones 3a-g are derived from 3,4-methylenedioxybenzaldehyde; chalcones $\mathbf{3 h}$-i from 4-nitrobenzaldeyde; chalcone $\mathbf{3 J}$ from 4-(N,N)-dimethylbenzaldehyde; chalcones 3k-1 from cinnamaldehyde; chalcones $\mathbf{3 m}$-r r from benzaldehyde and finally chalcones $\mathbf{3 s - u}$ from furfural. The chalcones were characterized by ${ }^{1} \mathrm{H}$ and ${ }^{13} \mathrm{C}$ nuclear magnetic resonance (NMR) spectroscopy, X-ray diffractometry and elemental analyses (for the novel compounds). The ${ }^{1} \mathrm{H}$ NMR spectra showed two doublets between 7.0 and $8.0 \mathrm{ppm}$ ( $J_{\text {trans }} 15-16 \mathrm{~Hz}$ ) confirming the trans configuration of the<smiles>COc1ccc(/C=C/C(=O)c2ccc(OC)c(OC)c2OC)cc1O</smiles><smiles>CS(=O)(=O)c1ccc(/C=C/C(=O)c2ccc(Br)cc2)cc1</smiles>

Fungicide $^{12}$ (IV)

olefins whereas the carbonyl carbons appear in the range of 187.7 to $193.7 \mathrm{ppm}$ in the ${ }^{13} \mathrm{C}$ NMR spectra.

Due to the wide spectrum of action of this class of compounds and to their good cytotoxicity, our group began to investigate some structural modifications based on related studies in order to obtain molecules with potential biological activity. Allyl chalcones in particular were reported to exhibit widespread biological activities, with improved activities in some cases, probably due to their structural similarity to licochalcone E. ${ }^{7}$ In our group, studies were carried out in this way, and the allyl group was introduced into the structures of chalcones $\mathbf{3 b}, \mathbf{3 n}$ and $\mathbf{3 t}$. Nevertheless, the insertions were not efficient, not reaching the expected activity.

\section{Biological activity}

Seven bacterial strains were used for testing antimicrobial activities, including Gram-positives: Sthaphylococcus aureus ATCC 6538, Bacillus subtilis ATCC 6833, Streptococcus mutans ATCC 25175, Micrococcus luteus ATCC 10240, and Gram-negatives: Escherichia coli ATCC 94863, Pseudomonas aeruginosa and Salmonella choleraesuis ATCC 14028. Three fungi were used: Aspergillus niger ATCC 16404, Cladosporium cladosporioides IMI 178517 and Candida albicans ATCC 18804. The results are summarized in Table 2 and indicate, in some cases, considerable activity against bacteria in comparison with the standard, especially for chalcones 3m, 3n and 3o, which showed a good profile towards some microorganisms (e.g., chalcone $\mathbf{3 n}$ on $S$. mutans). No activity at all was observed against the following microorganisms: S. choleraesuis ATCC 14028, E. Coli ATCC 94863 and $P$. aeruginosa.

In some cases, the activity is dependent on the substituents on the aromatic ring. For instance, chalcones 
3m-q, obtained from benzaldehyde, showed distinct activities against $S$. mutans (Table 2). The best activity was achieved when the hydroxyl group resides on the ortho position (as in $\mathbf{3 n}$ ). In contrast, the activity is diminished in 3o (OH in meta position) and in the absence of a substituent there was no activity. The protection of the hydroxyl group in 3n as an allyl ether decreased the activity by two dilutions. Chalcones derived from furaldehyde (3s-u) were somewhat active but those derived from piperonal (3a-g) were inactive irrespective of the substituents on the aromatic ring.

When the fungi are concerned, C. cladosporioides was the most sensitive to the chalcones. The greatest activities were achieved by compounds $\mathbf{3 a}, \mathbf{3 e}$ and $\mathbf{3 k}$. In the last two cases, the activities were at the same level of dilution as compared to Loprox ${ }^{\circledR}$, the standard drug used in the assay.

\section{Crystallographic analysis}

In order to get a better insight on the relationship between biological activity and structures, the crystal structure of seven chalcones were obtained for better characterization. Figure 3 shows the ORTEP drawings of chalcones 3a, 3f, 3i, 3n, 3o, 3q and $\mathbf{3 t}$ and the refinement data are shown in the Supplementary Information section.

\section{Principal component analysis (PCA) of chalcones}

The aim of this section is to get a relationship between geometric and electronic properties of the 21 synthesized chalcones and the biological activities against $S$. aureus ATCC 6538 and C. cladosporioides IMI 178517. For this purpose, quantum chemical calculations were carried out on chalcones and analogues, as listed in Table 1. The chalcones were tested against 10 microorganisms, but only two microorganisms were selected for this study, because the number of active and inactive chalcones for these two organisms is roughly equally distributed and this is very important for the statistical analysis of the calculated data to be meaningful, as shown in Table 3 .

As can be seen in Figure 3, chalcones are chemical compounds with several rotational degrees of freedom and, in turn, they present many geometric conformations
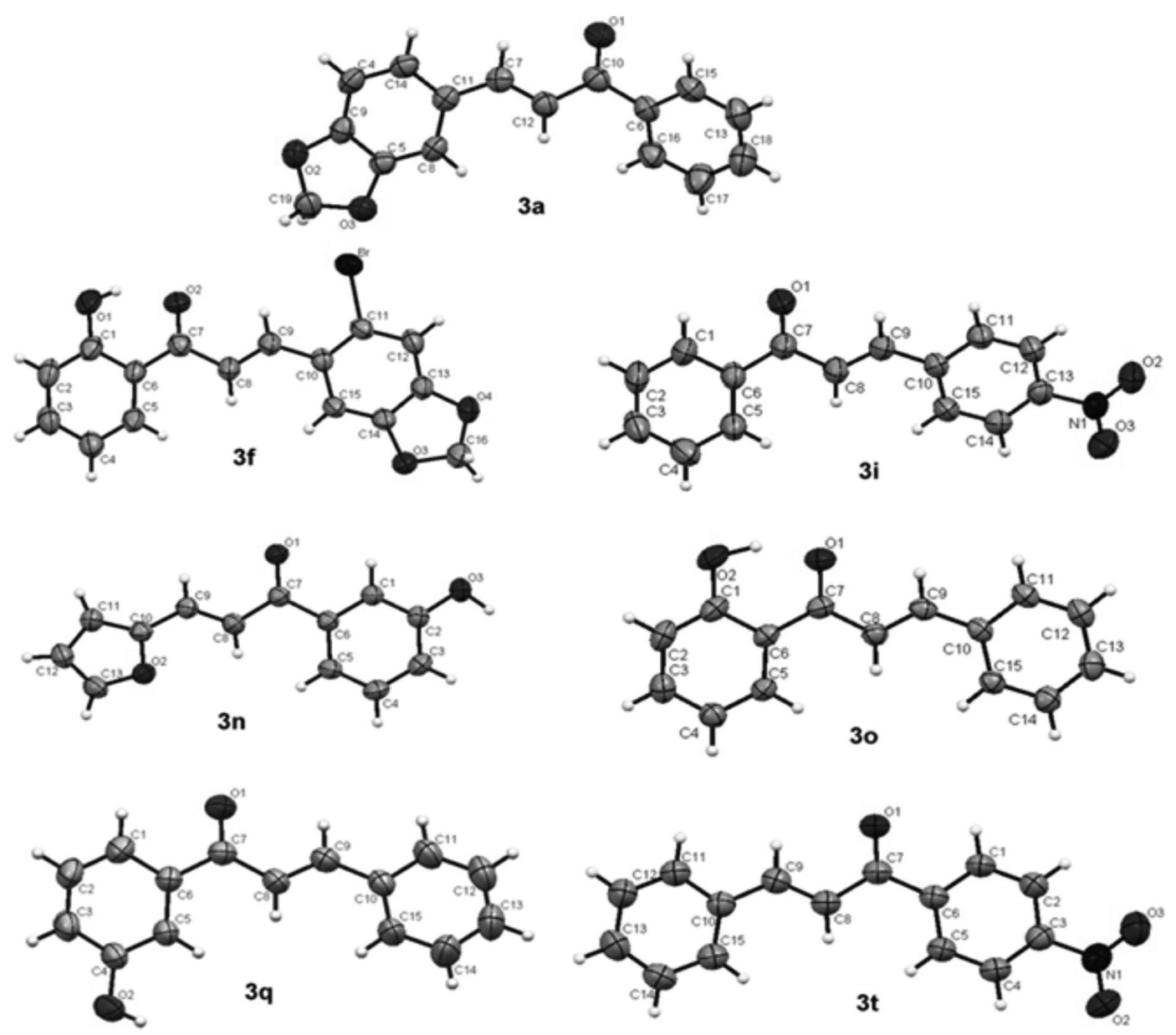

Figure 3. ORTEP drawings of chalcones $\mathbf{3 a}, \mathbf{3 f}, \mathbf{3 i}, \mathbf{3 n}, \mathbf{3 0}, \mathbf{3 q}$ and $\mathbf{3 t}$, with the atom-numbering schemes. The displacement ellipsoids are drawn at the $30 \%$ probability levels. 
Table 1. Synthesis of chalcones and analogues $\mathbf{3 a - 3 u}$

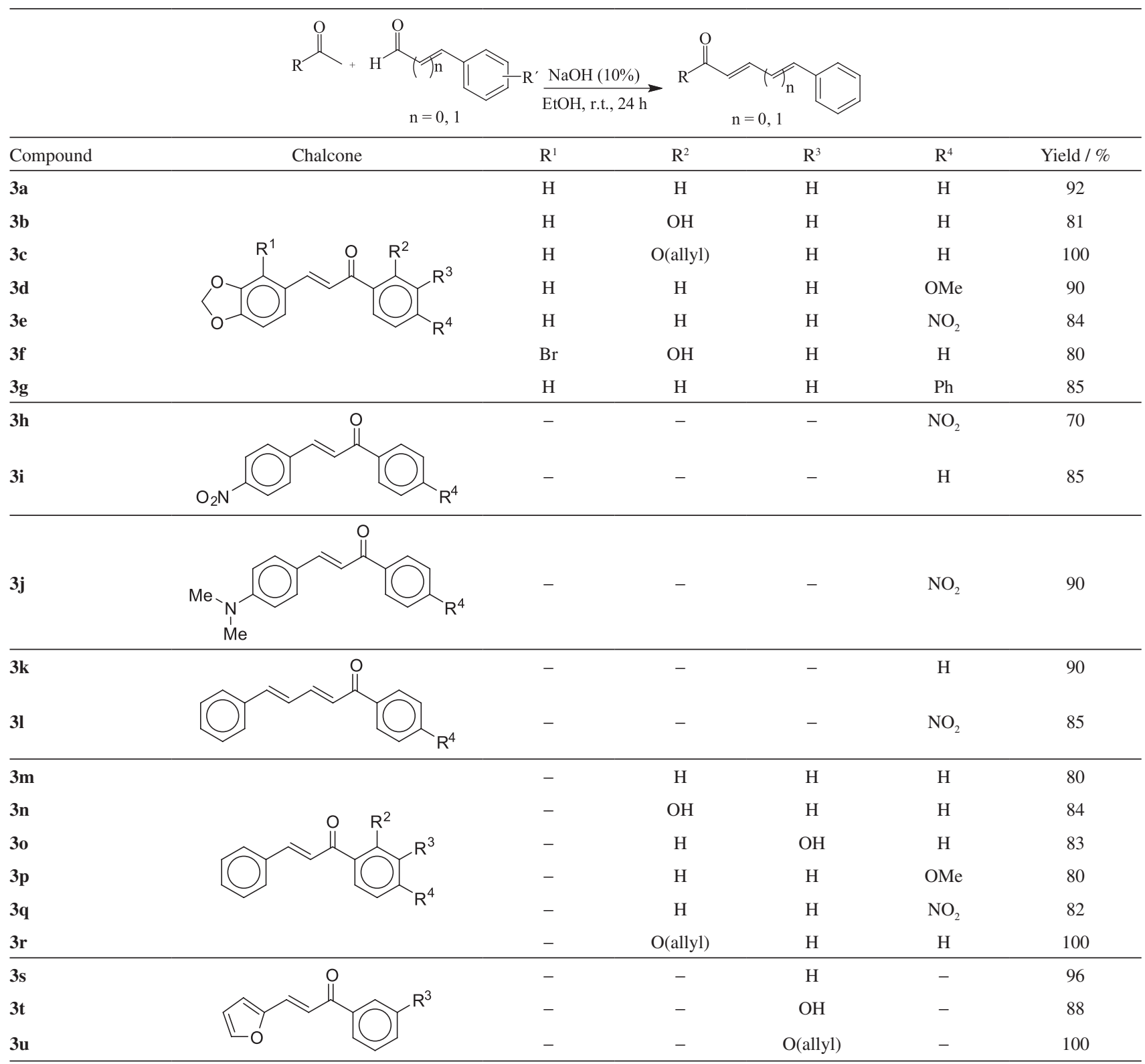

that are energetically stable. For this reason, it is mandatory to carry out a conformational search to find the molecular conformation with the lowest energy. In this work, the conformational searches were carried out using HyperChem ${ }^{\mathrm{TM}} 7.5$ suite of programs ${ }^{15}$ with semiempirical quantum method $\mathrm{PM} 3^{16,17}$ and random walk algorithm. Initially, the most active chalcone was analyzed and the most stable conformation was selected. Afterwards, the remaining chalcones were investigated and the energetically most stable conformation that was similar to the conformation selected before was chosen for the calculation of the molecular properties. Before calculating the properties, the molecular geometries were optimized again, but now using the density functional theory (DFT) $)^{18,19}$ with the hybrid exchange-correlation functional B3LYP ${ }^{20-22}$ and the basis set 6-31G(d) as implemented in the software package $\mathrm{G}_{09}{ }^{23}$, which was also used to calculate the molecular properties (descriptors or variables). In this work, the following molecular descriptors were calculated: HOMO-1 (second highest occupied molecular orbital energy), HOMO (highest occupied molecular orbital energy), LUMO (lowest unoccupied molecular orbital energy), LUMO+1 (second lowest unoccupied molecular orbital energy), partition coefficient $(\log \mathrm{P})$ (this property was obtained from the hydrophobic parameters of the substituents using HyperChem ${ }^{\mathrm{TM}}$ 7.5), Mulliken 
Table 2. Activities (MICs) of the chalcones against bacteria and fungi

\begin{tabular}{|c|c|c|c|c|c|c|c|c|c|c|}
\hline \multirow[b]{2}{*}{$\begin{array}{l}\text { Samples / } \\
\left(\mu \mathrm{g} \mathrm{mL} L^{-1}\right)\end{array}$} & \multicolumn{10}{|c|}{ Microrganisms } \\
\hline & $\begin{array}{c}\text { B. subtilis } \\
\text { ATCC } 6633\end{array}$ & $\begin{array}{c}\text { S. aureus } \\
\text { ATCC } 6538\end{array}$ & $\begin{array}{c}\text { M. luteus } \\
\text { ATCC } 10240\end{array}$ & $\begin{array}{c}\text { S. mutans } \\
\text { ATCC } 25175\end{array}$ & $\begin{array}{l}\text { S. choleraesuís } \\
\text { ATCC } 14028\end{array}$ & $\begin{array}{c}\text { E. coli } \\
\text { ATCC } 94863\end{array}$ & P. aeruginosa & $\begin{array}{c}\text { C. albicans } \\
\text { ATCC } 18804\end{array}$ & $\begin{array}{c}\text { A. niger } \\
\text { ATCC } 16404\end{array}$ & $\begin{array}{c}\text { C. cladosporioides } \\
\text { IMI } 178517\end{array}$ \\
\hline $3 \mathbf{a}$ & $>100$ & 100 & 100 & $>100$ & $>100$ & $>100$ & $>100$ & $>100$ & $>100$ & 12.5 \\
\hline $3 \mathbf{b}$ & $>100$ & $>100$ & $>100$ & $>100$ & $>100$ & $>100$ & $>100$ & $>100$ & 50 & $>100$ \\
\hline $3 \mathrm{c}$ & $>100$ & 50 & 100 & 100 & $>100$ & $>100$ & $>100$ & 100 & $>100$ & $>100$ \\
\hline 3d & $>100$ & 100 & $>100$ & 100 & $>100$ & $>100$ & $>100$ & $>100$ & 100 & 100 \\
\hline $3 e$ & $>100$ & $>100$ & $>100$ & $>100$ & $>100$ & $>100$ & $>100$ & $>100$ & $>100$ & 6,3 \\
\hline $3 f$ & $>100$ & $>100$ & $>100$ & $>100$ & $>100$ & $>100$ & $>100$ & $>100$ & 100 & $>100$ \\
\hline $3 g$ & $>100$ & $>100$ & $>100$ & $>100$ & $>100$ & $>100$ & $>100$ & $>100$ & $>100$ & $>100$ \\
\hline $3 \mathbf{h}$ & $>100$ & $>100$ & $>100$ & 100 & $>100$ & $>100$ & $>100$ & $>100$ & $>100$ & $>100$ \\
\hline $3 \mathbf{i}$ & $>100$ & $>100$ & $>100$ & $>100$ & $>100$ & $>100$ & $>100$ & $>100$ & $>100$ & $>100$ \\
\hline $3 \mathbf{j}$ & $>100$ & $>100$ & $>100$ & $>100$ & $>100$ & $>100$ & $>100$ & $>100$ & $>100$ & $>100$ \\
\hline $3 \mathbf{k}$ & $>100$ & $>100$ & $>100$ & $>100$ & $>100$ & $>100$ & $>100$ & 100 & $>100$ & 6.3 \\
\hline 31 & $>100$ & $>100$ & 100 & $>100$ & $>100$ & $>100$ & $>100$ & $>100$ & $>100$ & $>100$ \\
\hline $3 \mathrm{~m}$ & $>100$ & 25 & 100 & 100 & $>100$ & $>100$ & $>100$ & 50 & $>100$ & 25 \\
\hline $3 n$ & 100 & 25 & 25 & 12,5 & $>100$ & $>100$ & $>100$ & 100 & $>100$ & 25 \\
\hline 30 & 50 & 25 & 25 & 25 & $>100$ & $>100$ & $>100$ & 50 & 100 & 100 \\
\hline $3 p$ & $>100$ & 100 & 100 & $>100$ & $>100$ & $>100$ & $>100$ & $>100$ & $>100$ & $>100$ \\
\hline $3 q$ & $>100$ & $>100$ & $>100$ & $>100$ & $>100$ & $>100$ & $>100$ & $>100$ & $>100$ & $>100$ \\
\hline $3 r$ & $>100$ & 100 & 100 & 50 & $>100$ & $>100$ & $>100$ & $>100$ & $>100$ & $>100$ \\
\hline $3 s$ & $>100$ & 100 & 100 & 100 & $>100$ & $>100$ & $>100$ & $>100$ & $>100$ & 50 \\
\hline $3 t$ & 50 & 100 & 50 & 50 & $>100$ & $>100$ & $>100$ & $>100$ & $>100$ & 100 \\
\hline $3 u$ & $>100$ & 50 & 100 & 50 & $>100$ & $>100$ & $>100$ & 50 & $>100$ & $>100$ \\
\hline Chloramphenicol & 6.3 & 6.3 & 0.78 & 6.3 & 6.3 & 3.1 & 100 & - & - & - \\
\hline Loprox $®$ & - & - & - & - & - & - & - & 6.3 & 12.5 & 6.3 \\
\hline
\end{tabular}

Table 3. Theoretical values for the selected descriptors used in the PCA analysis for the activities against $C$. cladosporioides and $S$. aureus. The activities are also included

\begin{tabular}{|c|c|c|c|c|c|c|c|c|}
\hline \multirow{2}{*}{ Chalcone } & \multicolumn{4}{|c|}{ C. cladosporioides } & \multicolumn{4}{|c|}{ S. aureus } \\
\hline & $\mathrm{AD}_{1,2,3,4}$ & PsiH-13 & Ref & Activity & $\mathrm{b}_{7,14}$ & PsiL-2 & $\mathrm{A}_{12,2,3}$ & Activity \\
\hline $3 \mathbf{a}$ & -174.90 & 0.00 & 72.64 & active & 0.9023 & 11.76 & 118.126 & active \\
\hline $3 b$ & 173.37 & 0.00 & 68.50 & inactive & 1.1184 & 9.075 & 118.338 & inactive \\
\hline $3 c$ & 174.92 & 0.00 & 74.32 & inactive & 0.8945 & 6.371 & 119.975 & active \\
\hline $3 d$ & -175.08 & 0.00 & 88.27 & active & 0.9063 & 11.187 & 118.131 & active \\
\hline $3 e$ & 176.37 & 0.00 & 74.34 & active & 0.9053 & 10.078 & 117.849 & inactive \\
\hline $3 f$ & 174.09 & 0.00 & 68.57 & inactive & 0.8950 & 14.336 & 118.198 & inactive \\
\hline $3 g$ & 174.07 & 0.00 & 73.34 & inactive & 0.9005 & 20.293 & 118.183 & inactive \\
\hline $3 \mathbf{h}$ & 175.27 & 0.00 & 74.20 & inactive & 0.8982 & 4.842 & 118.25 & inactive \\
\hline $3 \mathbf{i}$ & 178.39 & 0.02 & 82.50 & inactive & 1.0147 & 18.849 & 117.72 & inactive \\
\hline $\mathbf{3 j}$ & 174.69 & 0.00 & 58.69 & inactive & 0.9024 & 11.011 & 120.045 & inactive \\
\hline $3 k$ & -174.43 & 0.00 & 79.11 & active & 0.9005 & 9.531 & 118.135 & inactive \\
\hline 31 & 174.43 & 0.00 & 60.39 & inactive & 0.9015 & 9.908 & 120.039 & inactive \\
\hline $3 m$ & -175.58 & 0.00 & 79.97 & active & 0.8984 & 2.275 & 118.204 & active \\
\hline $3 n$ & 177.96 & 0.06 & 81.89 & active & 1.1188 & 15.108 & 116.365 & active \\
\hline 30 & -179.18 & 0.24 & 97.78 & active & 0.8974 & 2.532 & 116.038 & active \\
\hline $3 p$ & 178.83 & 0.22 & 82.89 & inactive & 0.8916 & 3.368 & 117.105 & active \\
\hline $3 q$ & -174.68 & 0.00 & 81.53 & inactive & 0.8974 & 2.286 & 118.482 & inactive \\
\hline $3 r$ & -173.97 & 0.05 & 74.20 & inactive & 0.9014 & 5.034 & 118.433 & active \\
\hline $3 s$ & -175.92 & 0.00 & 88.56 & active & 0.8990 & 3.542 & 117.913 & active \\
\hline $3 t$ & -179.97 & 0.00 & 75.56 & active & 0.8967 & 10.289 & 117.424 & active \\
\hline $3 u$ & -175.92 & 0.00 & 66.88 & inactive & 0.9022 & 20.97 & 117.913 & active \\
\hline
\end{tabular}


electronegativity $\left(\chi=\left(E_{\text {номо }}-E_{\text {LUмо }}\right) / 2\right)$, dipole moment, molecular polarizability, total electronic energy, heat of formation, electron affinity (obtained as $-E_{\text {номо }}$ ), band gap energy $\left(E_{\text {LUмо }}-E_{\text {номо }}\right)$, hardness, softness, molar refractivity index, ionization potential energy, net atomic charge on atom derived from electrostatic potential, molecular area, molecular volume, bond order, bond length between adjacent atoms, angles between three consecutive atoms, dihedral angles between four consecutive atoms, molecular length, hydration energy, Psi $-x=\Sigma_{i}\left|c_{i}\right|_{\text {номо }}^{2}$ and Psi $-x=\Sigma_{i}\left|c_{i}^{2}\right|_{L U M O}^{2}$, where $x$ stands for atom number as shown in Figure 4.

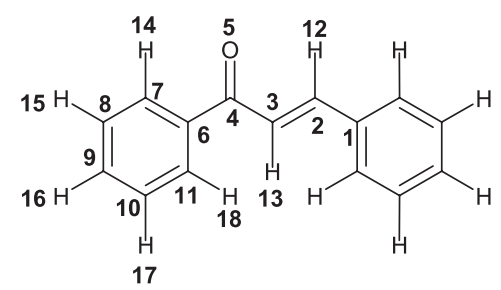

Figure 4. Atomic numbering used in the calculations of the molecular descriptors.

The frontier electron reactivity theory, which explains many organic reactions, states that the reaction between two reactants takes place where the overlap of HOMO and LUMO is maximized. ${ }^{24}$ The HOMO density (PsiH- $x$ ) is closely related to the charge transfer (nucleophilic reactant), while for an acceptor compound the LUMO density (PsiL- $x$ ) is important (electrophilic reactant). A total of 118 geometrical and electronic molecular descriptors was obtained from ab initio calculations in such a way that they can represent electronic, steric and hydrophobic features of the chalcones. These features are supposed to be important to elucidate the biological activity of the chalcones against S. aureus ATCC 6538 and C. cladosporioides IMI 178517.

In order to find a relationship between the calculated descriptors and the biological activities, an analysis using the multivariate statistical was carried out using the Einsight program. ${ }^{25}$ At the outset, the Fisher weight ${ }^{26}$ for each descriptor was calculated in order to discriminate those variables that are the most important to separate the active from the inactive chalcones. The Fisher weight $\left(w_{k}\right)$ for the variable $k$ was obtained from the following equation 1 :

$w_{k}($ active, inactive $)=\frac{\left(\bar{x}_{\text {active }}-\bar{x}_{\text {active }}\right)^{2}}{\left(1 / N_{\text {active }}\right) \sum\left(x_{\text {active }}-\bar{x}_{\text {active }}\right)^{2}+\left(1 / N_{\text {inactive }}\right) \sum\left(x_{\text {inactive }}-\bar{x}_{\text {inactive }}\right)^{2}}$

In this equation, $\bar{x}_{\text {active }}$ and $\bar{x}_{\text {inactive }}$ are the mean values for the active and inactive molecules and $\left(1 / N_{\text {active }}\right) \sum\left(x_{\text {active }}-\bar{x}_{\text {active }}\right)^{2}$ and $\left(1 / N_{\text {inactive }}\right) \sum\left(x_{\text {inactive }}-\bar{x}_{\text {inactive }}\right)^{2}$ are the respective variances. Those descriptors with high Fisher weights are more significant to discriminate the compounds between active and inactive, allowing, in this way, a reduction in the number of variables to be used in PCA.

The major aim in the PCA technique is to reduce the dimensionality of the data set to lower dimensional space for analysis. ${ }^{27}$ This is achieved through an orthogonal linear transformation of the original data set of descriptors into a smaller set of uncorrelated significant principal components (PCs). This transformation can be seen as a rotation of the original coordinate system in such a way that the first principal component (PC1) axis describes the maximum variance of the data set. The second principal component (PC2), which is orthogonal to the first one, describes the second maximum variance and so on. In general, the great majority of the variance of the data set is described by the first components and can be utilized to represent the entire data set in a simplified way. For this reason, principal component analysis is a useful tool for helping in the visualization of hidden patterns, providing descriptive models. A priori, all descriptors are likewise important to explain the biological activity. So, before applying PCA technique, the data were auto-scaled, i.e., each variable was mean centered and divided by standard deviation, so each variable in the matrix data can be compared to each other on the same scale. The auto-scaling procedure was calculated according to equation 2 ,

$x_{i k}=\left(x_{i}-\bar{x}_{i}\right) / \sqrt{\sigma_{i}^{2}}$

where $x_{i k}$ represents the auto-scaled variable $i$ for the sample $k, \sqrt{\sigma_{i}^{2}}$ stands for standard deviation and $\bar{x}_{i}$ is the mean value of the variable $i$.

\section{Activity against C. cladosporioides IMI 178517}

The atomic numbering used in the calculation of the molecular descriptors is shown in Figure 4. After several attempts to separate the active from the inactive chalcones against $C$. cladosporioides IMI 178517, the best result was finally obtained with three descriptors: dihedral angle between atoms 1, 2, 3, and 4 (DA1,2,3,4), (PsiH-13), and refractive index (Ref) (the names in parenthesis represent the names of the respective descriptors plotted in Figure 5). Figure 6 shows the score plots. Observe that two components (PC1 and PC2) are necessary to discriminate the chalcones into active and inactive. These two principal components together explain $89.33 \%$ of the total variance in the data set as follows: $\mathrm{PC} 1=56.32 \%$ and $\mathrm{PC} 2=33.01 \%$. The amount of total variance explained in the data set by these two components represents very well the higher order space. The score plot in Figure 6 shows that the 


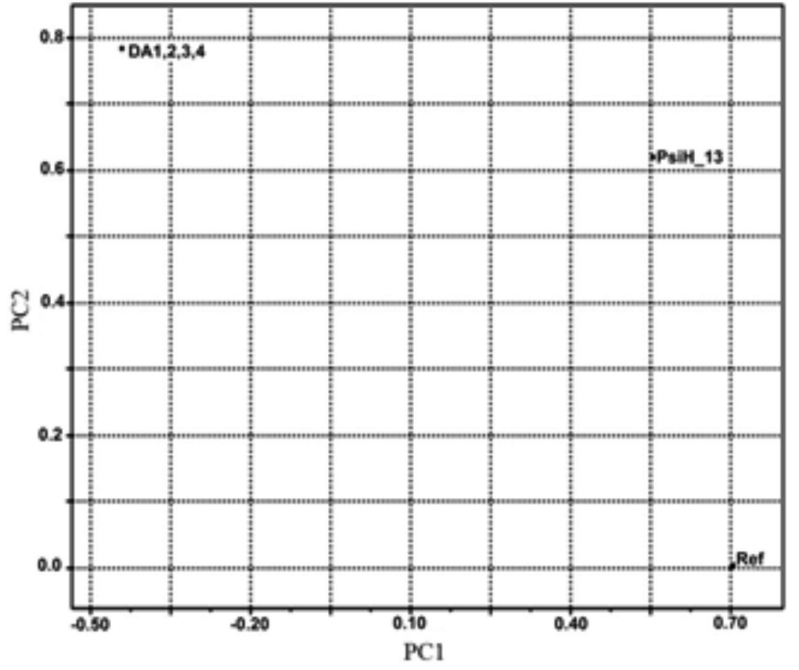

Figure 5. Plot showing the descriptor loadings, which explain the activity of the compounds against $C$. cladosporioides. DA1,2,3,4 stands for dihedral angle among the atoms 1, 2, 3 and 4, PsiH-13 represents the HOMO density on atom 13 and Ref stands for molecular refractive index.

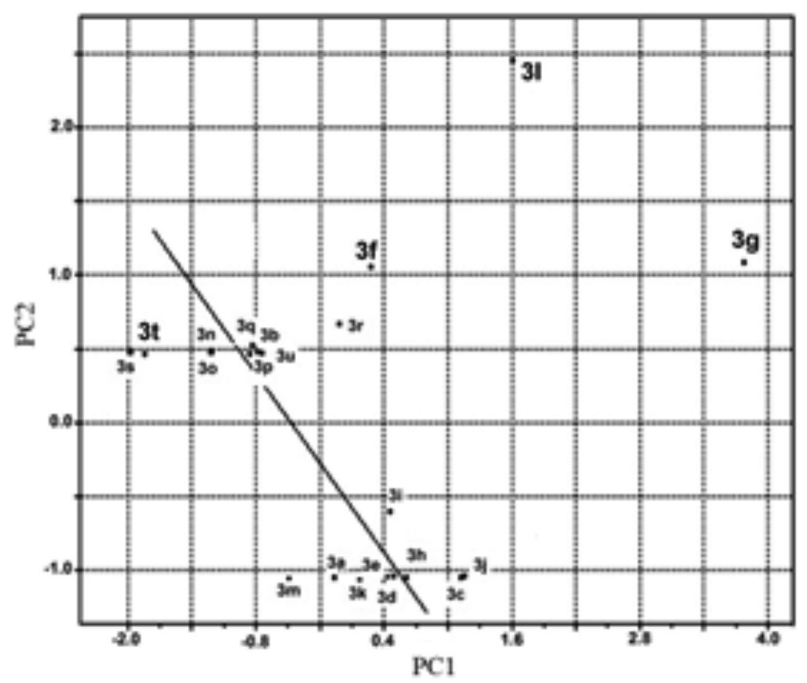

Figure 6. Plot showing the scores for the activity of the chalcone derivatives against $C$. cladosporioides. It is worth noting that all the active compounds (3a, 3d, 3e, 3k, 3m, 3n, 3o, 3s and 3t) stand below the solid line drawn in figure.

active chalcones against $C$. cladosporioides are gathered below the solid line drawn in the figure. The mathematic representations for these two components are expressed through equations 3 and 4 .

$$
\begin{aligned}
& \mathrm{PC} 1=0.7046 \text { Ref }+0.5552 \mathrm{PsiH}-13-0.4419 \mathrm{DA}_{1,2,3,4} \\
& \mathrm{PC} 2=0.0033 \text { Ref }+0.6202 \mathrm{PsiH}-13-0.7845 \mathrm{DA}_{1,2,3,4}
\end{aligned}
$$

From analysis of equations 3 and 4, it is possible to see that the variable Ref is not meaningful in the second component but is very important in the first component. The other descriptors, namely PsiH-13 and dihedral angle between atoms 1, 2, 3, and 4 (DA1,2,3,4) are important in both components. For a chalcone to be classified as active against $C$. cladosporioides, it must stand below the solid line drawn in Figure 6. This means that the scores for both components should be small and, in turn, for the scores to be small, the variables Ref and PsiH-13 should present lower values. However, as shown in equations 3 and 4, the situation for the variable DA1,2,3,4 is a little delicate because it should present higher value in the first component (the loading is negative for this variable in PC1) and lower value in the second one (the loading is positive) in order to help in the discrimination of the compounds. As shown in Table 3, the value of this dihedral angle is almost $180^{\circ}$, which means that the chalcones are almost planar in this molecular region. PsiH-13 describes the HOMO density on atom 13 and, according to equations 1 and 2, it should have lower values in order to help in the discrimination of the compounds. From these observations, it is possible to hypothesize the three major characteristics for a chalcone to be active: (i) lower values of refractive index (Ref), (ii) lower values of the HOMO density on atom 13 (PsiH-13) (see Figure 4 for the numbering), and (iii) intermediate values of dihedral angle between the atoms 1, 2, 3 and 4 (DA1,2,3,4). These molecular characteristics can help us to design new chalcones with activity against $C$. cladosporioides.

\section{Activity against $S$. aureus ATCC 6538}

The active chalcones against $S$. aureus ATCC 6538 stand above the solid line drawn in Figure 7. As can be noted in this figure, only one component (PC2) is needed to separate the active chalcones from the inactive ones. The component PC2 accounts for $33.02 \%$ of the total variance of the original data, while the first component (PC1) accounts for $46.62 \%$. Both components added up to $79.64 \%$ of the total variance in the original data. A close look in equation 5 and in Figure 8 shows that the descriptors responsible for the discrimination are the angle between atoms 12, 2 and 3 (A12-2-3), PsiL-2, and bond order between atoms 7 and 14 (b7,14). Equation 5 also shows that for a compound to fall in the active group, it should present higher values of PsiL-2 and A12-2-3 variables. The bond order b7-14 is not important in this component, but to run the Einsight program, ${ }^{25}$ it was necessary to include it in the calculation.

$\mathrm{PC} 1+0.001 \mathrm{~b} 7.14+0.694 \mathrm{PsiL} 2+0.720 \mathrm{~A} 12,2,3$

As pointed out before, the variable PsiL-2 is closely related to the importance of the atom 2 in the lowest unoccupied molecular orbital (LUMO). Equation 5 shows that this descriptor should be higher for the molecule to be active. That may mean that the atom 2 (Figure 4 ) could be 


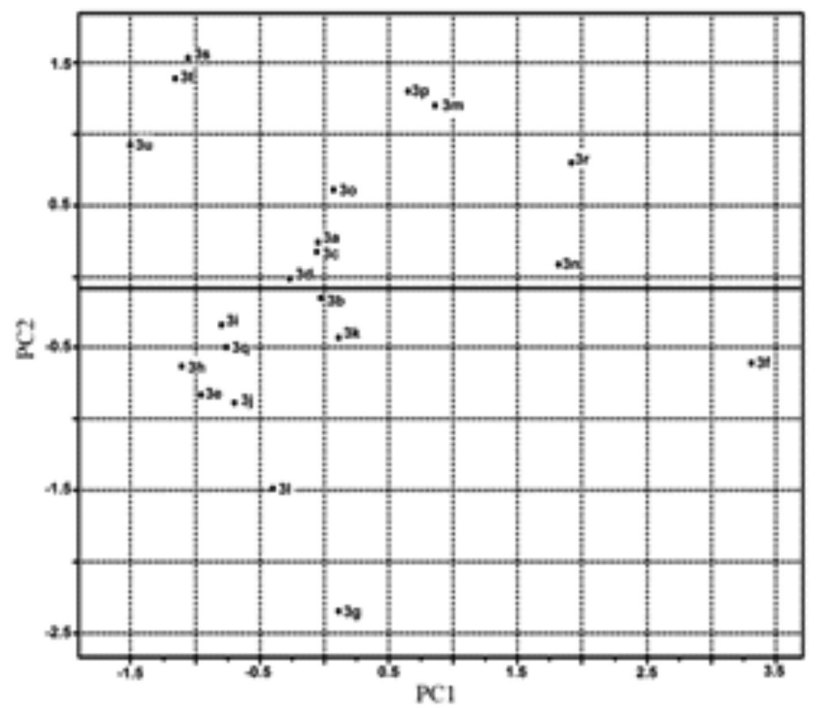

Figure 7. Plot showing the scores for the activity of the compound derivatives against $S$. aureus. Note that all the active compounds stand above the solid line drawn in figure.



Figure 8. Graphic representation of variable loadings (A12,2,3, PsiL-2, $\mathrm{b} 7,14)$ that discriminate the active from the inactive chalcones against S. aureus.

involved in the formation of some kind of chemical bond in the structure of S. aureus ATCC 6538. From that discussion, it is possible to postulate that the chalcones studied need to present two main characteristics to express activity against $S$. aureus ATCC 6538: (i) they must have a large angle between atoms 12, 2 and 3 (A12,2,3), and (ii) they need to increase the value of LUMO density, which is probably related to some kind of reaction in expressing their activities. This characteristic can be useful in designing compounds with activity against $S$. aureus ATCC 6538.

\section{Conclusions}

A series of chalcones was prepared and evaluated against bacteria and fungi. Some compounds showed promising activity against C. cladosporioides, with low inhibitory values, in some cases in the same order of magnitude as the standard $\left(\right.$ Loprox $\left.^{\circledR}\right)$. Chemometric studies were employed to find a possible structure-activity relationship and allowed to establish some important features for the chalcones to be active. For instance, the best activity against $C$. cladosporioides IMI 178517 was obtained with three descriptors: dihedral angle between atoms, HOMO density on atom 13 (PsiH-13) and refractivity index (Ref) and two components (PC1 and PC2) were necessary to discriminate the chalcones into active and inactive. In the case of S. aureus ATCC 6538, only one component (PC2) was needed and the descriptors responsible for the discrimination were the bond angle (A12-2-3), PsiL-2, and bond order between atoms (b7,14). Future efforts to optimize the structures of this class of compounds may involve design, as well as the study of the effect of some groups strategically placed in positions in the structure of chalcones that may influence some properties such as solubility.

\section{Experimental}

\section{General}

All reagents were obtained from Sigma-Aldrich and used without purification. ${ }^{1} \mathrm{H}$ NMR spectra were recorded at $300 \mathrm{MHz}$ on a Varian Mercury Plus 7.04 T spectrometer and chemical shifts were reported relative to internal $\mathrm{Me}_{4} \mathrm{Si}$. ${ }^{13} \mathrm{C}$ NMR spectra were recorded at $75 \mathrm{MHz}$ on a Varian Mercury Plus 7.04 T spectrometer and chemical shifts were reported relative to internal $\mathrm{CDCl}_{3}$. The infrared spectra were obtained on a Bomem MB-100 spectrometer. Elemental analyses were obtained on a Perkin Elmer series II CHNS/O Analyzer 2400.

\section{General synthetic procedure for chalcones}

The ketone $(1 \mathrm{mmol})$ was added to a solution of $\mathrm{NaOH}(10 \% \mathrm{~m} / \mathrm{v})$ and ethanol $(3 \mathrm{~mL})$ and the mixture was stirred for 20 min under ice bath cooling. Then, the aldehyde $(1 \mathrm{mmol})$ was added and the resulting mixture was stirred overnight at room temperature. The reaction mixture was acidified with $10 \% \mathrm{HCl}$. The precipitate was collected, washed with cold water, dried and purified by recrystallization from EtOH or in appropriate solvents (generally chloroform and methylene chloride). The chalcones that did not crystallize were washed with chloroform and purified by column chromatography (20\% ethyl acetate/hexane). 


\section{MIC assays}

The determinations of MIC were performed essentially according to the National Committee for Clinical Laboratory Standards (NCCLS) ${ }^{28}$ as described by Ellof ${ }^{29}$ and Kusucu et al. ${ }^{30}$ The microorganisms were obtained from the Fundação Tropical de Pesquisa e Tecnologia André Tosello, Campinas-SP, Brazil, with exception of E. coli and P. aeruginosa, obtained from Departamento de Farmácia of Universidade Federal da Bahia, Salvador-BA, Brazil. The bacteria were grown for $24 \mathrm{~h}$ at $35^{\circ} \mathrm{C}$ on nutrient agar. The fungi and yeast were cultivated for $72 \mathrm{~h}$ at $26^{\circ} \mathrm{C}$ on malt extract agar and yeast malt agar, respectively. The inocula for the assays were prepared by cell suspensions according to McFarland scale 0.5 (108 CFU $\left.\mathrm{mL}^{-1}\right)$.

To determine MIC of the compounds against the microorganisms, the following modified micro dilution method was carried out: the compounds were dissolved in sterile dimethyl sulfoxide (2000 $\left.\mathrm{mg} \mathrm{mL}^{-1}\right)$ and $20 \mu \mathrm{L}$ of the stock solutions were transferred into 96 well sterile microtiter plates. Then, serial dilutions with nutrient broth to bacteria and malt extract broth to fungi were performed, so that the concentrations of the tested compounds ranged from 100 to $0.78 \mathrm{mg} \mathrm{mL}^{-1}$. Finally, an aliquot $(100 \mu \mathrm{L})$ of culture medium containing the microorganism suspension was added to the wells. Chloramphenicol and Loprox ${ }^{\circledR}$ were used as the reference drugs against bacteria and fungi, respectively, and DMSO was used as negative control. The plates were incubated at $35^{\circ} \mathrm{C}$ for $24 \mathrm{~h}$ to bacteria and fungi and yeast were maintained at $26^{\circ} \mathrm{C}$ for $72 \mathrm{~h}$. After incubation, an aliquot of $50 \mu \mathrm{L}$ of aqueous [3-(4,5-dimethyl-2-tiazolyl)-2,5 diphenyl-2H-tetrazolium bromide] (MTT at $0.05 \%$ ) was added on the wells and the reduction of tetrazolium salt (yellow) from (blue) indicated the presence of viable cells. MIC is defined as the lowest concentration of the substances which inhibited the growth of the microorganisms.

Crystallographic structure determinations of compounds 3a, 3f, 3i, 3n, 3o, 3q and $3 t$

Single crystal X-ray diffraction data were collected at room temperature using a Nonius CAD-4 diffratometer ${ }^{31}$ and using $\mathrm{Cu} \mathrm{K}_{\alpha}$ radiation $(\lambda=1.54180 \AA)$. The structures were solved by direct methods and anisotropically refined with full-matrix least-squares on F2 using SHELXL97. ${ }^{32}$ The hydrogen atoms were placed at calculated position except those involved in $\mathrm{H}$-bonds and weak interactions found on difference maps and refined with riding constraints. With regard to the hydrogen atoms, those bonded to carbon atoms were placed in expected positions according to the stereochemical predictions. They were refined with fixed individual displacement parameters $20 \%$ greater than the equivalent isotropic displacement parameter of the corresponding carbon atom. Aromatic $\mathrm{C}-\mathrm{H}$ bond distances were fixed according to the riding model $(0.93 \AA)$. The ( $x, y$, $z$ ) fractional coordinates and the isotropic thermal parameter of these $\mathrm{H}$ atoms were not constrained during refinements. The Mercury ${ }^{33}$ and ORTEP- $3^{34}$ programs were used within the WinGX ${ }^{35}$ software package to deal with the processed crystallographic data and artwork representations. The conformational and geometric features of this molecule were checked comparing with other similar structures. The crystallographic data for compounds $\mathbf{3 f}, \mathbf{3 i}, \mathbf{3 a}, \mathbf{3 n}$ and 3t were deposited at the Cambridge Crystallographic Data Center under the numbers 819655, 819656, 819657, 819681 and 823762 , respectively.

The respective solutions, anisotropic refinements, geometrical calculations, molecular packing and drawings were performed using the program package WINGX. (3a): $\mathrm{C}_{16} \mathrm{H}_{12} \mathrm{O}_{3}, a=7.809(2), b=11.1764(9), c=28.601(2) \AA$, orthorhombic system, space group Pcab, $R=0.0557$; (3f): $\mathrm{C}_{16} \mathrm{H}_{11} \mathrm{O}_{4} \mathrm{Br}, a=4.160(3), b=11.757(2), c=27.598(7) \AA$, $\beta=92.87(4)^{\circ}$, monoclinic system, space group $\mathrm{P} 21 / \mathrm{c}$, $R=0.0809 ;(3 \mathbf{i}): \mathrm{C}_{15} \mathrm{H}_{11} \mathrm{NO}_{3}, a=4.7580(9), b=6.096(1)$, $c=10.658(2) \AA, \alpha=95.807(2)^{\circ}, \beta=90.482(2)^{\circ}$, $\gamma=96.397(2)^{\circ}$, triclinic system, space group $\mathrm{P} 1$, $R=0.0492 ;$ (3t): $\mathrm{C}_{13} \mathrm{H}_{10} \mathrm{O}_{3}, a=3.9530(9), b=14.583(2)$, $c=17.893(5) \AA$, monoclinic, space group $\mathrm{P} 21 / \mathrm{n}$, $R=0.0527$; (3o): $\mathrm{C}_{15} \mathrm{H}_{12} \mathrm{O}_{2}: a=12.641(1), b=12.066(2)$, $c=7.813(1) \AA, \beta=101.278(9)^{\circ}$, monoclinic system, space group P21/c, $R=0.0820$; (3n): $\mathrm{C}_{15} \mathrm{H}_{12} \mathrm{O}_{2}, a=6.822(2)$, $b=10.474(4), c=17.097(2) \AA, \alpha=73.88(2), \beta=84.29(2)$, $\gamma=87.66(3)^{\circ}$. Triclinic, space group P-1, $R=0.0701$; (3q): $\mathrm{C}_{15} \mathrm{H}_{11} \mathrm{NO}_{3}, a=6.299(3), b=13.226(3), c=14.809 \AA$, $\beta=99.73(9)^{\circ}$, monoclinic system, space group $\mathrm{P} 21 / \mathrm{c}$, $R=0.0660$.

\section{Spectroscopic data for the chalcones}

(2E)-3-(1,3-Benzodioxol-5-yl)-1-phenylprop-2-en-1-one (3a): ${ }^{36} \mathrm{IR}(\mathrm{KBr}) \mathrm{v}_{\max } / \mathrm{cm}^{-1} 3021,2928,1660,1598,1503$, 1310, 1104, 770, 686; ' $\mathrm{H}$ NMR (300 MHz, $\mathrm{CDCl}_{3}$ ) 8.027.98 (m, 2H), 7.73 (d, 1H, J 15.7 Hz), 7.61-7.46 (m, 3H), 7.36 (d, 1H, J 15.7 Hz), 7.16 (d, 1H, J 1.4 Hz), 7.11 (dd, $1 \mathrm{H}, J 8.1$ and $1.9 \mathrm{~Hz}), 6.84(\mathrm{~d}, 1 \mathrm{H}, J 8.1 \mathrm{~Hz}), 6.02(\mathrm{~s}, 2 \mathrm{H})$; ${ }^{13} \mathrm{C}$ NMR (75 MHz, $\mathrm{CDCl}_{3}$ ) 190.4, 149.9, 148.4, 144.7, $138.3,132.6,129.3,128.5,128.4,125.2,120.0,108.6$, 106.6, 101.6.

(E)-3-(Benzo[d][1,3]dioxol-6-yl)-1-(2-hydroxyphenyl) prop-2-en-1-one (3b): ${ }^{36}{ }^{1} \mathrm{H}$ NMR (300 MHz, $\left.\mathrm{CDCl}_{3}\right) 12.90$ 
(s, 1H), $7.90(\mathrm{dd}, 1 \mathrm{H}, J 6.6$ and $1.4 \mathrm{~Hz}), 7.85(\mathrm{~d}, 1 \mathrm{H}$, $J 15.3 \mathrm{~Hz}), 7.50(\mathrm{~d}, 1 \mathrm{H}, J 15.3 \mathrm{~Hz}), 7.52-7.47(\mathrm{~m}, 1 \mathrm{H}), 7.18$ (dd, $1 \mathrm{H}, J 6.9$ and $1.7 \mathrm{~Hz}), 7.14(\mathrm{~d}, 1 \mathrm{H}, J 1.45 \mathrm{~Hz}), 7.03$ (dd, $1 \mathrm{H}, J 8.4$ and $0.9 \mathrm{~Hz}), 6.97-6.91(\mathrm{~m}, 1 \mathrm{H}), 6.82(\mathrm{~d}, 1 \mathrm{H}$, J $8.1 \mathrm{~Hz}), 6.05(\mathrm{~s}, 2 \mathrm{H}) ;{ }^{13} \mathrm{C} \mathrm{NMR}\left(75 \mathrm{MHz}, \mathrm{CDCl}_{3}\right) 193.5$, $163.5,150.3,148.5,145.3,136.2,129.5,129.0,125.7$, 120.0, 118.8, 118.6, 117.9, 108.7, 106.7, 101.7.

(E)-1-(2-(allyloxy)phenyl)-3-(benzo[d][1,3]dioxol-6-yl) prop-2-en-1-one (3c): ${ }^{1} \mathrm{H}$ NMR (300 $\left.\mathrm{MHz}, \mathrm{CDCl}_{3}\right) 7.64$ $(\mathrm{dd}, 1 \mathrm{H}, J 7.4$ and $1.8 \mathrm{~Hz}), 7.56(\mathrm{~d}, 1 \mathrm{H}, J 15.7 \mathrm{~Hz}), 7.47-$ $7.41(\mathrm{~m}, 1 \mathrm{H}), 7.30(\mathrm{~d}, 1 \mathrm{H}, J 15.7 \mathrm{~Hz}), 7.09-6.96(\mathrm{~m}, 4 \mathrm{H})$, $6.81(\mathrm{~d}, 1 \mathrm{H}, J 7.8 \mathrm{~Hz}), 6.10-5.97(\mathrm{~m}, 3 \mathrm{H}), 5.42(\mathrm{dq}, 1 \mathrm{H}$, $J 3.0$ and $1.5 \mathrm{~Hz}$ ), $5.26(\mathrm{dq}, 1 \mathrm{H}, J 3.0$ and $1.5 \mathrm{~Hz}) ;{ }^{13} \mathrm{C} \mathrm{NMR}$ $\left(75 \mathrm{MHz}, \mathrm{CDCl}_{3}\right)$ 192.5, 157.0, 149.5, 148.2, 142.6, 132.7, 132.5, 130.4, 129.7, 129.5, 125.2, 124. 9, 120.9, 117.6, 112.8, 108.5, 106.5, 101.5, 69.2 anal. calcd. for $\mathrm{C}_{16} \mathrm{H}_{14} \mathrm{O}_{3}: \mathrm{C}$, 75.57; H, 5.55; O, 18.88; found: C, 75.48; H, 5.51; O, 19.01.

(E)-3-(Benzo[d][1,3]dioxol-6-yl)-1-(4-methoxyphenyl) prop-2-en-1-one (3d): ${ }^{36}{ }^{1} \mathrm{H}$ NMR $\left(300 \mathrm{MHz}, \mathrm{CDCl}_{3}\right)$ 7.99-8.05 (m, 2H), $7.73(\mathrm{~d}, 1 \mathrm{H}, J 15.6 \mathrm{~Hz}), 7.38(\mathrm{~d}, 1 \mathrm{H}$, $J 15.9 \mathrm{~Hz}), 7.17(\mathrm{~d}, 1 \mathrm{H}, J 1.9 \mathrm{~Hz}), 7.11(\mathrm{dd}, 1 \mathrm{H}, J 8.4$ and $1.9 \mathrm{~Hz}), 6.95-7.00(\mathrm{~m}, 1 \mathrm{H}), 6.83(\mathrm{~d}, 2 \mathrm{H}, J 7.8 \mathrm{~Hz}), 6.02$ (s, 2H), 3.88 (s, 3H); ${ }^{13} \mathrm{C}$ NMR (75 MHz, $\left.\mathrm{CDCl}_{3}\right) 188.5$, 163.3, 149.7, 148.3, 143.8, 131.2, 130.7, 129.5, 125.0, 119.9, 113.8, 108.6, 106.6, 101.6, 55.5.

(E)-3-(Benzo[d][1,3]dioxol-6-yl)-1-(4-nitrophenyl)prop2-en-1-one (3e): ${ }^{36}{ }^{1} \mathrm{H} \mathrm{NMR}\left(300 \mathrm{MHz}, \mathrm{CDCl}_{3}\right)$ 8.37-8.32 $(\mathrm{m}, 2 \mathrm{H}), 8.15-8.11(\mathrm{~m}, 2 \mathrm{H}), 7.78(\mathrm{~d}, 1 \mathrm{H}, J 15.4 \mathrm{~Hz}), 7.31$ (d, $1 \mathrm{H}, J 15.4 \mathrm{~Hz}), 7.18-7.13(\mathrm{~m}, 2 \mathrm{H}), 6.88(\mathrm{~d}, 1 \mathrm{H}, J 8.1 \mathrm{~Hz})$, $6.06(\mathrm{~s}, 2 \mathrm{H}) ;{ }^{13} \mathrm{C}$ NMR $\left(75 \mathrm{MHz}, \mathrm{CDCl}_{3}\right)$ 188.8, 150.7, $150.6,148.6,146.7,143.3,129.3,128.8,126.0,123.9$, $119.2,108.8,106.7,101.8$.

(E)-3-(4-Bromobenzo[d][1,3]dioxol-5-yl)-1-(2-hydroxyphenyl) prop-2-en-1-one (3f): ${ }^{1} \mathrm{H}$ NMR (300 MHz, $\mathrm{CDCl}_{3}$ ) $12.80(\mathrm{~s}, 1 \mathrm{H}), 8.23(\mathrm{~d}, 1 \mathrm{H}, J 15.6 \mathrm{~Hz}), 7.88(\mathrm{dd}, 1 \mathrm{H}$, $J 8.1$ and $1.7 \mathrm{~Hz}), 7.53-7.47(\mathrm{~m}, 1 \mathrm{H}), 7.44(\mathrm{~d}, J 15.6 \mathrm{~Hz})$, $7.23(\mathrm{~s}, 1 \mathrm{H}), 7.10(\mathrm{~s}, 1 \mathrm{H}), 7.03(\mathrm{dd}, 1 \mathrm{H}, J 8.1$ and $1.7 \mathrm{~Hz})$, 6.97-6.91 (m, 1H), $6.06(\mathrm{~s}, 2 \mathrm{H}) ;{ }^{13} \mathrm{C}$ NMR $(75 \mathrm{MHz}$, $\left.\mathrm{CDCl}_{3}\right)$ 193.3, 163.6, 150.6, 148.0, 143.7, 136.4, 129.6, 127.9, 120.7, 119.9, 118.9, 118.7, 113.4, 106.5, 102.4. Anal. Calcd. for $\mathrm{C}_{16} \mathrm{H}_{11} \mathrm{BrO}_{4}: \mathrm{C}, 55.36 ; \mathrm{H}, 3.19$. Found: C, 55,$25 ; \mathrm{H}, 3.16$.

(E)-3-(Benzo[d][1,3]dioxol-6-yl)-1-(4-phenyl)prop-2-en1-one (3g): ${ }^{37}{ }^{1} \mathrm{H}$ NMR (300 MHz, $\mathrm{CDCl}_{3}$ ) 8.11-8.08 (m, 2H), $7.78(\mathrm{~d}, 1 \mathrm{H}, J 15.7 \mathrm{~Hz}), 7.74-7.64(\mathrm{~m}, 4 \mathrm{H}), 7.51-7.38$ (m, 3H), $7.43(\mathrm{~d}, J 15.7 \mathrm{~Hz}, 1 \mathrm{H}), 7.20(\mathrm{~d}, 1 \mathrm{H}, J 1.8 \mathrm{~Hz})$,
7.15 (dd, $1 \mathrm{H}, J 8.0$ and $1.4 \mathrm{~Hz}), 6.85(\mathrm{~d}, 1 \mathrm{H}, J 8.0 \mathrm{~Hz}), 6,03$ (s, 2H); ${ }^{13} \mathrm{C}$ NMR (75 MHz, $\mathrm{CDCl}_{3}$ ) 189.7, 149.9, 148.4, 145.4, 144.6, 139.9, 137.0, 129.4, 129.0, 128.9, 128.1, $127.3,127.2,125,3,119.9,108.7,106.7,101.6$.

(E)-1,3-bis(4-nitrophenyl)prop-2-en-1-one (3h): ${ }^{38}$ ${ }^{1} \mathrm{H}$ NMR $\left(300 \mathrm{MHz}, \mathrm{CDCl}_{3}\right)$ 8.41-8.37 (m, $\left.1 \mathrm{H}\right), 8.34-8.28$ (m, 3H), 8.21-8.16 (m, 2H), 7.91-7.81 (m, 3H), 7.61 (d, $1 \mathrm{H}, J 15.5 \mathrm{~Hz}) ;{ }^{13} \mathrm{C}$ NMR $\left(75 \mathrm{MHz}, \mathrm{CDCl}_{3}\right) 188.2,143.4$, $142.2,140.3,129.5,129.4,129.2,124.7,124.3,124.2$, $124.0,123.8$.

(2E)-3-(4-Nitrophenyl)-1-phenylprop-2-en-1-one (3i): ${ }^{39}$ ${ }^{1} \mathrm{H}$ NMR (300 MHz, $\mathrm{CDCl}_{3}$ ) 8.30-8.25 (m, 2H), 8.06$8.02(\mathrm{~m}, 2 \mathrm{H}), 7.85-7.75(\mathrm{~m}, 3 \mathrm{H}), 7.82(\mathrm{~d}, 1 \mathrm{H}, J 15.6 \mathrm{~Hz})$; ${ }^{13} \mathrm{C}$ NMR (75 MHz, $\mathrm{CDCl}_{3}$ ) 189.6, 148.5, 141.4, 141.0, $137.4,133.3,128.9,128.8,128.5,125.6,124.1$.

(E)-3-(4-(Dimethylamino)phenyl)-1-(4-nitrophenyl)prop2-en-1-one (3j): ${ }^{40} \mathrm{H}$ NMR (300 MHz, $\left.\mathrm{CDCl}_{3}\right)$ 8.38-8.31 (m, 2H), 8.15-8.09 (m, 2H), $7.82(\mathrm{~d}, 1 \mathrm{H}, J 15.3 \mathrm{~Hz}), 7.58$ 7.54 (m, 2H), 7.27 (d, 1H, J 15.3 Hz), 6.73-6.69 (m, 2H); ${ }^{13} \mathrm{C}$ NMR $\left(75 \mathrm{MHz}, \mathrm{CDCl}_{3}\right.$ ) 188.9, 152.3, 149.6, 147.8, 144.2, 130.9, 129.1, 123.7, 122.2, 116.0, 111.9, 40.2.

(2E,4E)-1,5-Diphenylpenta-2,4-dien-1-one (3k): ${ }^{41}$ IR (film) $v_{\max } / \mathrm{cm}^{-1} 3059,3027,1676,1594,1448,1034,776$, 700; ${ }^{1} \mathrm{H}$ NMR (300 MHz, $\mathrm{CDCl}_{3}$ ) 8.03-7.93 (m, 2H), 7.63$7.22(\mathrm{~m}, 10 \mathrm{H}), 7.13-6.92(\mathrm{~m}, 2 \mathrm{H}) ;{ }^{13} \mathrm{C} \mathrm{NMR}(75 \mathrm{MHz}$, $\left.\mathrm{CDCl}_{3}\right)$ 190.3, 144.7, 141.8, 138.1, 135.9, 132.5, 129.1, $129.0,128.8,128.7,128.5,128.4,128.3,127.2,126.8,125.2$.

(2E,4E)-1-(4-Nitrophenyl)-5-phenylpenta-2,4-dien1-one (3l): ${ }^{41}{ }^{1} \mathrm{H} \mathrm{NMR}\left(300 \mathrm{MHz}, \mathrm{CDCl}_{3}\right)$ 8.36-8.32 (m, $2 \mathrm{H}), 8.12-8.08(\mathrm{~m}, 2 \mathrm{H}), 7.66(\mathrm{dd}, 1 \mathrm{H}, J 8.8$ and $1.5 \mathrm{~Hz})$, 7.54-7.50 (m, 2H), 7.43-7.35 (m, 3H), 7.07-7.02 (m, 3H); ${ }^{13} \mathrm{C}$ NMR $\left(75 \mathrm{MHz}, \mathrm{CDCl}_{3}\right)$ 188.9, 149.9, 146.7, 143.6, $143.1,135.7,129.7,129.3,128.9,128.6,127.5,126.5$, $124.5,123.8,123.5$.

(2E)-1,3-Diphenylprop-2-en-1-one (3m):42 IR ( $\mathrm{KBr}$ ) 3056, 1661, 1605, 1576, 1448, 746, $689 \mathrm{~cm}^{-1}$. ${ }^{1} \mathrm{H}$ NMR (300 MHz, $\left.\mathrm{CDCl}_{3}\right)$ 8.01-7.97 (m, 2H), $7.77(\mathrm{~d}, 1 \mathrm{H}$, $J 15.9 \mathrm{~Hz}), 7.55-7.24$ (m, 9H); ${ }^{13} \mathrm{C} \mathrm{NMR}\left(75 \mathrm{MHz}, \mathrm{CDCl}_{3}\right)$ 189.5, 144.1, 137.6, 134.3, 132.3, 130.0, 128.4, 128.1, 128.0, 128.0, 121.4 .

(E)-1-(2-Hydroxyphenyl)-3-phenylprop-2-en-1-one (3n): ${ }^{43}{ }^{1} \mathrm{H} \mathrm{NMR}\left(300 \mathrm{MHz}, \mathrm{CDCl}_{3}\right) 12.82(\mathrm{~s}, 1 \mathrm{H}), 7.95-7.91$ (m, 2H), 7.69-7.64 (m, 3H), 7.54-7.43 (m, 3H), 7.05-6.93 (m, 2H); ${ }^{13} \mathrm{C}$ NMR (75 MHz, $\mathrm{CDCl}_{3}$ ) 193.7, 163.6, 145.5, 
136.4, 134.6, 130.9, 129.6, 129.0, 128.7, 120.1, 118.8, 118.6 .

(E)-1-(3-Hydroxyphenyl)-3-phenylprop-2-en-1-one (3o): ${ }^{43}{ }^{1} \mathrm{H}$ NMR (300 MHz, DMSO- $d_{6}$ ): 9.89 (s, $\left.1 \mathrm{H}\right)$, 7.92-7.85 (m, 3H), 7.75 (d, 1H, J 15.6 Hz), $7.65(\mathrm{dd}, 1 \mathrm{H}$, $J 1.5$ and $1.1 \mathrm{~Hz}), 7.50-7.38(\mathrm{~m}, 5 \mathrm{H}), 7.09(\mathrm{dd}, 1 \mathrm{H}, J 2.6$ and $0.9 \mathrm{~Hz}) ;{ }^{13} \mathrm{C}$ NMR (75 MHz, $\mathrm{CDCl}_{3}$ ) 189.5, 169.3, 150.9, $145.5,139.6,134.7,130.7,129.7,129.0,128.5,126.1$, $125.9,121.7,121.7$.

(E)-1-(4-Methoxyphenyl)-3-phenylprop-2-en-1-one (3p): ${ }^{39}{ }^{1} \mathrm{H}$ NMR $\left(300 \mathrm{MHz}, \mathrm{CDCl}_{3}\right)$ 8.07-8.02 (m, 2H), $7.80(\mathrm{~d}, 1 \mathrm{H}, J 15.7 \mathrm{~Hz}), 7.66-7.63(\mathrm{~m}, 2 \mathrm{H}), 7.55(\mathrm{~d}, 1 \mathrm{H}$, $J$ 15.7 Hz), 7.43-7.39 (m, 3H), 7.00-6.96 (m, 2H), 3.88 (s, 3H); ${ }^{13} \mathrm{C}$ NMR (75 MHz, $\mathrm{CDCl}_{3}$ ) 188.7, 163.4, 143.9, 135.0, 131.0, 130.8, 130.3, 128.9, 128.3, 121.8, 113.8, 55.4 .

(E)-1-(4-Nitrophenyl)-3-phenylprop-2-en-1-one (3q): ${ }^{39}$ ${ }^{1} \mathrm{H}$ NMR $\left(300 \mathrm{MHz}, \mathrm{CDCl}_{3}\right.$ ) 8.37-8.32 (m, 2H), 8.17-8.12 (m, 2H), $7.85(\mathrm{~d}, 1 \mathrm{H}, J 15.6 \mathrm{~Hz}), 7.69-7.63(\mathrm{~m}, 2 \mathrm{H}), 7.49$ (d, $1 \mathrm{H}, J 15.6 \mathrm{~Hz}), 7.47-7.43(\mathrm{~m}, 3 \mathrm{H}) ;{ }^{13} \mathrm{C}$ NMR $(75 \mathrm{MHz}$, $\mathrm{CDCl}_{3}$ ) 189.0, 150.0, 146.8, 143.0, 134.2, 131.2, 129.4, 129.1, 128.7, 123.8, 121.2.

(E)-1-(2-(Allyloxy)phenyl)-3-phenylprop-2-en-1-one (3r): ${ }^{44}{ }^{1} \mathrm{H} \mathrm{NMR}\left(300 \mathrm{MHz}, \mathrm{CDCl}_{3}\right)$ 7.68-7.64 (m, 1H), 7.63$7.56(\mathrm{~m}, 2 \mathrm{H}), 7.49-7.43$ (m, 2H), 7.41-7.36 (m, 3H), 7.05 $(\mathrm{td}, 1 \mathrm{H}, J 7.5$ and $1.4 \mathrm{~Hz}), 6.98(\mathrm{dd}, 1 \mathrm{H}, J 8.2$ and $0.7 \mathrm{~Hz})$, 6.10-5.97 (m, 1H), $5.42(\mathrm{dq}, 1 \mathrm{H}, J 2.8$ and $1.4 \mathrm{~Hz}), 5.24$ (dq, $1 \mathrm{H}, J 2.8$ and $1.4 \mathrm{~Hz}$ ), $4.64(\mathrm{dt}, 3 \mathrm{H}, J 3.2$ and $1.4 \mathrm{~Hz}$ ); ${ }^{13} \mathrm{C}$ NMR (75 MHz, $\mathrm{CDCl}_{3}$ ) 192.7, 157.1, 142.7, 135.0, $132.9,132.5,130.5,130.1,129.5,128.8,128.3,127.1$, $120.9,117.7,112.8,69.2$.

(2E)-3-(2-Furyl)-1-phenylprop-2-en-1-one (3s): ${ }^{45}$ IR (film) $\mathrm{v}_{\text {max }} / \mathrm{cm}^{-1} 3129,3067,1663,1603,1552,1223,1013$, 971, 884, 776; ${ }^{1} \mathrm{H}$ NMR (300 MHz, $\left.\mathrm{CDCl}_{3}\right)$ 8.04-7.99 (m, $2 \mathrm{H}), 7.58(\mathrm{~d}, 1 \mathrm{H}, J 15.4 \mathrm{~Hz}), 7.58-7.51(\mathrm{~m}, 1 \mathrm{H}), 7.50-7.42$ (m, 4H), $7.44(\mathrm{~d}, 1 \mathrm{H}, J 15.4 \mathrm{~Hz}) ;{ }^{13} \mathrm{C}$ NMR $(75 \mathrm{MHz}$, $\left.\mathrm{CDCl}_{3}\right)$ 189.8, 151.6, 144.9, 132.7, 130.7, 128.5, 128.4, 119.2, 116.3, 112.6.

(2E)-3-(2-Furyl)-1-(3-hydroxyphenyl)prop-2-en-1-one (3t): ${ }^{45} \mathrm{IR}(\mathrm{KBr}) v_{\max } / \mathrm{cm}^{-1} 3261,3128,1647,1595,1551$, 1276, 1022, 980, 777; ${ }^{1} \mathrm{H}$ NMR $\left(300 \mathrm{MHz}, \mathrm{CDCl}_{3}\right) 7.87$ (d, $J 7.8 \mathrm{~Hz} ; 1 \mathrm{H}), 7.73(\mathrm{t}, 1 \mathrm{H}, J 2.2 \mathrm{~Hz}), 7.58(\mathrm{~d}, 1 \mathrm{H}, J 15.1 \mathrm{~Hz})$, 7.52-7.47 (m, 2H), 7.37 (d, 1H, J 15.1 Hz), 7.35-7.28 (m, $1 \mathrm{H}), 6.71(\mathrm{~d}, 1 \mathrm{H}, J 3.4 \mathrm{~Hz}), 6.49(\mathrm{dd}, 1 \mathrm{H}, J 3.4$ and $1.9 \mathrm{~Hz})$, 2.33 (s, 3H); ${ }^{13} \mathrm{C}$ NMR (75 MHz, $\mathrm{CDCl}_{3}$ ) 189.30, 169.26,
$150.81,145.34,142.31,139.59,135.94,129.58,129.28$, $128.82,128.48,127.29,126.74,124.97,121,55.125 .86$, $125.68,21.06$

(E)-1-(3-(Allyloxy)phenyl)-3-(furan-2-yl)prop-2-en-1-one (3u): ${ }^{1} \mathrm{H} \mathrm{NMR}\left(300 \mathrm{MHz}, \mathrm{CDCl}_{3}\right)$ 7.63-7.52 (m, 4H), 7.45$7.36(\mathrm{~m}, 2 \mathrm{H}), 7.12(\mathrm{dd}, 1 \mathrm{H}, J 2.6$ and $0.7 \mathrm{~Hz}), 6.71(\mathrm{~d}, 1 \mathrm{H}$, $J 3.4 \mathrm{~Hz}$ ), 6.50 (dd, $1 \mathrm{H}, J 3.4$ and $1.9 \mathrm{~Hz}$ ), 6.14-6.01 (m, $1 \mathrm{H}), 5.44(\mathrm{dq}, 1 \mathrm{H}, J 3.1$ and $1.5 \mathrm{~Hz}), 5.31(\mathrm{dq}, 1 \mathrm{H}, J 3.1$ and $1.5 \mathrm{~Hz}), 4.61(\mathrm{dt}, 2 \mathrm{H}, \mathrm{J} 3.1$ and $1.5 \mathrm{~Hz}) ;{ }^{13} \mathrm{C} \mathrm{NMR}(75 \mathrm{MHz}$, $\left.\mathrm{CDCl}_{3}\right)$ 189.2, 158.7, 151.5, 144.8, 139.3, 132.7, 130.5, 129.4, 120.9, 119.7, 119.1, 117.8, 116.2, 113.5, 112.6, 68.7; anal. calcd. for $\mathrm{C}_{19} \mathrm{H}_{16} \mathrm{O}_{4}: \mathrm{C}, 74.01 ; \mathrm{H}, 5.23 ; \mathrm{O}, 20.76$; found: C, 73.93; H, 5.19; O, 20.88.

\section{Supplementary Information}

Data spectra and spectra of synthesized compounds are available free of charge at http://jbcs.sbq.org.br as PDF file.

\section{Acknowledgments}

We thank the Instituto de Química, Universidade de Brasília, FINEP-CT INFRA No. 970/01, Conselho Nacional de Desenvolvimento Científico e Tecnológico (CNPq), PrP/UEG and FUNAPE/UFG for financial support.

\section{References}

1. Daskiewicz, J.-B.; Depeint, F.; Viornery, L.; Bayet, C.; Comte-Sarrazin, G.; Comte, G.; Gee, J. M.; Johnson, I, T.; Ndjoko, K.; Hostettmann, K.; Barron, D.; J. Med. Chem. 2005, 48, 2790.

2. Reddy, M. V. B.; Hwang, T.; Leu, Y.; Chiou, W.; Wu, T.; Bioorg. Med. Chem. 2011, 19, 2751.

3. Aponte, J. C.; Castillo, D.; Estevez, Y.; Gonzales, G.; Arevalo, J.; Hammond, G. B.; Sauvain, M.; Bioorg. Med. Chem. Lett. 2010, 20, 100.

4. Dyrager, C.; Wickström, M.; Fridén-Saxin, M.; Friberg, A.; Dahlén, K.; Wallén, E. A. A.; Gullbo, J.; Grotli, M.; Luthman, K.; Bioorg. Med. Chem. 2011, 19, 2659; Ruan, B.; Lu, X.; Tang, J.; Wei, Y.; Wang, X.; Zhang, Y.; Wang, L.; Zhu, H.; Bioorg. Med. Chem. 2011, 19, 2688.

5. Cheenpracha, S.; Karalai, C.; Ponglimanont, C.; Subhadhirasakul, S.; Tewtrakal, S.; Bioorg. Med. Chem. 2005, 14, 1710.

6. Wattenberg, L. W.; Coccia, J. B.; Galhaith, A. R.; Cancer Lett. 1994, 83, 165.

7. Yoon, G.; Lee, W.; Kim, S.-N.; Cheon, S. H.; Bioorg. Med. Chem. Lett. 2009, 19, 5155; Monti, S.; Manet, I.; Manoli, F.; Marconi, G.; Phys. Chem. Chem. Phys. 2008, 10, 6597. 
8. Gordon, L. T.; Weitzman, S. A.; Cancer J. 1993, 6, 257.

9. Wang, Q.; Ding, Z.-H.; Liu, J.-K.; Zheng, Y.-T.; Antiviral Res. 2004, 64, 189.

10. Quintin, J.; Desrivot, J.; Thoret, S.; Le Menez, P.; Cresteil, T.; Lewin, G.; Bioorg. Med. Chem. Lett. 2009, 19, 167.

11. Bandgar, B. P.; Gawande, S. S.; Bodade, R. G.; Gawande, N. M.; Khobragade, C. N.; Bioorg. Med. Chem. 2009, 17, 8168.

12. Sivakumar, P. M.; Kumar, T. M.; Doble, M.; Chem. Biol. Drug Des. 2009, 74, 68.

13. Vencato, I.; Andrade, C. K. Z.; Silva, W. A.; Lariucci, C.; Acta Crystallogr., Sect. E: Struct. Rep. Online 2006, 62, o1033; Silva, W. A.; Gatto, C. C.; Oliveira, G. R.; Acta Crystallogr., Sect. E: Struct. Rep. Online 2011, 67, o2210.

14. Lawrence, N. J.; Rennison, D.; McGown, A. T.; Ducki, S.; Gul, L. A.; Hadfield, J. A.; Khan, N.; J. Comb. Chem. 2001, 3, 421.

15. HyperChemTM Professional 7.51, Hypercube, Inc., $1115 \mathrm{NW}$ 4th Street, Gainesville, Florida 32601, USA.

16. Stewart, J. J. P.; J. Comp. Chem. 1989, 10, 209.

17. Stewart, J. J. P.; J. Comp. Chem. 1989, 10, 221.

18. Hohenberg, P.; Kohn, W.; Phys. Rev. 1964, 136, B864.

19. Kohn, W.; Sham, L.; Phys. Rev. 1965, 140, A1133.

20. Becke, A. D.; J. Chem. Phys. 1993, 98, 5648.

21. Lee, C.; Yang, W.; Parr, R. G.; Phys. Rev. 1988, B37, 785.

22. Miehlich, B.; Savin, A.; Stoll, H.; Preuss, H.; Chem. Phys. Lett. 1989, 157, 200.

23. Frisch, M. J.; Trucks, G. W.; Schlegel, H. B.; Scuseria, G. E.; Robb, M. A.; Cheeseman, J. R.; Scalmani, G.; Barone, V.; Mennucci, B.; Petersson, G. A.; Nakatsuji, H.; Caricato, M.; Li, X.; Hratchian, H. P.; Izmaylov, A. F.; Bloino, J.; Zheng, G.; Sonnenberg, J. L.; Hada, M.; Ehara, M.; Toyota, K.; Fukuda, R.; Hasegawa, J.; Ishida, M.; Nakajima, T.; Honda, Y.;., Kitao, O.; Nakai, H.; Vreven, T.; Montgomery, J. A. Jr.; Peralta, J. E.; Ogliaro, F.; Bearpark, M.; Heyd, J. J.; Brothers, E.; Kudin, K. N.; Staroverov, V. N.; Kobayashi, R.; Normand, J.; Raghavachari, K.; Rendell, A.; Burant, J. C.; Iyengar, S. S.; Tomasi, J.; Cossi, M.; Rega, N.; Millam, J. M.; Klene, M.; Knox, J. E.; Cross, J. B.; Bakken, V.; Adamo, C.; Jaramillo, J.; Gomperts, R.; Stratmann, R. E.; Yazyev, O.; Austin, A. J.; Cammi, R.; Pomelli, C.; Ochterski, J. W.; Martin, R. L.; Morokuma, K.; Zakrzewski, V. G.; Voth, G. A.; Salvador, P.; Dannenberg, J. J.; Dapprich, S.; Daniels, A. D.; Farkas, Ö.; Foresman, J. B.; Ortiz, J. V.; Cioslowski, J.; Fox, D. J.; Gaussian 09, Revision A.1; Gaussian, Inc.: Wallingford, CT, USA, 2009.

24. Fukui, K.; Theory of Orientation and Stereoselection; SpringerVerlag: New York, 1975, p. 34.

25. Einsight 3.0 Infometrix, Suite 833; Infometrix, Inc.: Seattle, WA, USA, 1991.

26. Sharaf, M. A.; Illman, D. L.; Kolwalski, B. R.; Chemometrics; Wiley: New York, USA, 1986.
27. Brereton, R. G.; Chemometrics: Data Analysis for the Laboratory and Chemical Plant; Wiley: Chichester, USA, 2003.

28. National Committee for Clinical Laboratory Standards (NCCLS); Methods for Dilution Antimicrobial Susceptibility Tests for Bacteria that Grow Aerobically: Approved Standard, M7-A55th, $5^{\text {th }}$ ed.; NCCLS: Wayne, PA, 2000.

29. Ellof, J. N.; Planta Medica 1998, 64, 711.

30. Kusucu, C.; Rapino, B.; McDermott, L.; Hadley, S.; J. Clin. Microbiol. 2004, 42, 1224.

31. Enraf-Nonius; $C A D-4 / P C$ Software, version 1.2; Enraf-Nonius: Delft, The Netherlands, 1993.

32. Sheldrick, G. M.; SHELXS97 and SHELXL97; University of Göttingen: Germany, 1997.

33. Macrae, C. F.; Edgington, P. R.; McCabe, P.; Pidcock, E.; Shields, G. P.; Taylor, R.; Towler, M.; van de Streek, J.; J. Appl. Cryst. 2006, 39, 453.

34. Johnson, C. K.; ORTEP-II: a FORTRAN Thermal-Ellipsoid Plot Program for Crystal Structure Illustrations; Oak Ridge National Laboratory Report ORNL-5138: Tennessee, USA, 1976.

35. Farrugia, L. J.; J. Appl. Cryst. 1997, 30, 565.

36. Chiaradia, L. D.; Mascarello, A.; Purificação, M.; Vernal, J.; Cordeiro, M. N. S.; Zenteno, M. E.; Villarino, A.; Nunes, R. J.; Yunes, R. A.; Terenzi, H.; Bioorg. Med. Chem. Lett. 2008, $18,6227$.

37. Buu-Hoi, Ng. Ph.; Loc, T. B.; Xuong, Ng. D.; Bull. Soc. Chim. Fr. 1955, 694.

38. Solhy, A.; Tahir, R.; Sebti, S.; Skouta, R.; Bousmina, M.; Zahmely, M.; Larzek, M.; Appl. Catal., A 2010, 374, 189.

39. Zhu, Y.-W.; Yi, W.-B.; Cai, C.; J. Fluorine Chem. 2011, 71.

40. Pang, S.; Jian, F.; Xuan, Z.; Wang, J.; Crystal Growth Des. 2009, 9, 43.

41. Santos, C. M. M.; Silva, A. M. S.; Cavaleiro, J. A. S.; Lévai, A.; Patonay, T.; Eur. J. Org. Chem. 2007, 2877.

42. Hayat, F.; Salahuddin, A.; Umar, S.; Azam, A.; Eur. Med. Chem. 2010, 45, 4669.

43. Karki, R.; Thapa, P.; Kang, M. J.; Jeong, T. C.; Namb, J. M.; Kim, H.-L.; Na, Y.; Cho, W.-J.; Kwon, Y.; Lee, E.-S.; Bioorg. Med. Chem. 2010, 18, 306.

44. Saito, T.; Nagashima, M.; Karakasa, T.; Motoki, S.; J. Chem. Soc. Chem. Commun. 1992, 411.

45. Cetin, A.; Cansiz, A.; Digrak, M.; Heteroat. Chem. 2003, 14, 345.

46. Zhao, P.-L.; Liu, C.-L.; Huang, W.; Wang, Y.-Z.; Yanga, G.-F.; J. Agric. Food Chem. 2007, 55, 5697.

Submitted: September 21, 2012 Published online: February 19, 2013 